\title{
DISKURSUS PENEGAKAN HAK ASASI MANUSIA DI ASEAN DAN AFRICA UNION SEBAGAI ORGANISASI REGIONAL
}

\author{
Grace Christinery Kuhe1, Abas Kaluku² \\ ${ }^{1}$ Universitas Padjajaran, Indonesia, ${ }^{2}$ Universitas Negeri Gorontalo, Indonesia \\ gracechristinery@gmail.com, abaskaluku57@gmail.com
}

\begin{abstract}
Abstrak
Perkembangan kontemporer perlindungan HAM telah jauh berkembang hal ini dapat di lihat banyak kawasan regional yang telah mengatur prinsip-prinsip HAM dalam piagam pendirian contohnya Piagam ASEAN dan African Union Constitutive Act. ASEAN dan Africa Union (AU), di anggap sebagai representatif perlindungan HAM di kawasan regional akan tetapi berbeda dengan AU, ASEAN masih jauh tertinggal secara konsep hal ini di buktikan masih kuatnya prinsip kedaulatan negara dan prinsip non-intervensi di kawasan ASEAN. Adapun yang menjadi rumusan masalah yaitu adanya diskursus terkait penerapan prinsip non intervensi, kedaulatan negara dan intervensi kemanusian yang menjadi inti permasalahan penegakan HAM di ASEAN. Penelitian ini menggunakan Metode Penelitian Hukum Normatif, menggunakan pendekatan konsep dan pendekatan perbandingan. Untuk dapat mengatasi permasalah pelanggaran HAM di ASEAN maka: (1) ASEAN perlu melakukan pertemuan antar negara guna memperoleh penyelesain permasalahan HAM di dasarkan atas kemufakatan; (2) ASEAN perlu melakukan peninjauan kembali terhadap penerapan prinsip kedaulatan negara dan non intervensi dengan melihat perkembangan hukum internasional kontemporer (3) ASEAN perlu berkomitmen penuh terhadap AICHR guna mendukung ekosistem perlindungan dan penegakan HAM di ASEAN.
\end{abstract}

Kata Kunci: HAM; Non-Intervensi; Kedaulatan Negara; Intervensi Kemanusiaan

\begin{abstract}
The contemporary development of human rights protection has been far developed, this can be seen in many regional areas that have regulated human rights principles in the founding charter, for example the ASEAN Charter and the African Union Constitutive Act. ASEAN and the Africa Union (AU) are considered representatives of human rights protection in the region, but in contrast to the AU, ASEAN is still far behind in concept, this is proven by the strength of the principle of state sovereignty and the principle of non-intervention in the ASEAN region. As for the formulation of the problem, namely the existence of a discourse related to the application of the principle of non-intervention, state sovereignty and humanitarian intervention which are at the core of the problem of human rights enforcement in ASEAN. This research uses the Normative Law Research Method, using a conceptual approach and a comparative approach. To be able to overcome the problem of human rights violations in ASEAN: (1) ASEAN needs to hold a meeting between ASEAN countries in order to resolve human rights issues based on an agreement; (2) ASEAN needs to conduct a review of the application of the principle of state sovereignty and non-intervention by looking at developments in contemporary international law; (3) ASEAN needs to be fully committed to AICHR in order to support an ecosystem for the protection and enforcement of human rights in ASEAN.
\end{abstract}

Keywords: Human Rights; Non-Intervention; State Sovereignty; Humanitarian Intervention 


\section{PENDAHULUAN}

\section{Latar Belakang}

Piagam Perserikatan BangsaBangsa (PBB) menjadi awal lahirnya pandangan terhadap pentingnya promosi dan pemajuan HAM untuk mencapai kemerdekaan, keadilan dan perdamaian dunia. PBB sejak awal pembentukannya berusaha memaksimalkan upaya terhadap pemajuan dan penegakan HAM negaranegara di dunia. Namun upaya perbaikan struktural yang berkelanjutan dalam hak asasi manusia ternyata tidaklah mudah untuk dicapai. Hal ini dibuktikan dengan berbagai laporan terkait adanya pelanggaran integritas dan pelanggaran hak asasi, dimana terdapat negara yang pemerintahnya melakukan penyiksaan bahkan pembunuhan terhadap warga sipil, masih adanya konflik bersenjata, serta kejahatan terhadap pelanggaran HAM lainnya.

Prinsip kedaulatan negara dan prinsip non intervensi yang diwujudkan dalam hukum internasional sering kali menjadi hambatan bagi PBB maupun

\footnotetext{
1 Lihat Article 2 (7) Charter of The United Nation

2 Pernyataan asli Kofi Anan: "Just as we have learned that the world cant stand aside when gross and systematic violations of human rights are taking place, so we have also learned that intervention must be based on legitimate and universal principles if it is to enjoy the sustained support of the world's peoples.
}

komunitas Internasional untuk berperan signifikan dalam penyelesaian permasalahan yang ada. Pasal 2 (7) Piagam PBB $^{1}$ merupakan salah satu perwujudan dari prinsip non intervensi yang telah diterapkan dalam hukum internasional.

Kofi Annan selaku Sekjen PBB memberikan pernyataan :

"bahwa penerapan intervensi kemanusian harus tetap berdasarkan pada kaidah dan norma hukum internasional walaupun dalam perkembanganya banyak menemui tantangan akan tetapi intervensi kemanusian harus di liat dari perpesktif yang lebih komperhensif yaitu tanggung jawab untuk melindungi. ${ }^{2}$

Kofi Annan juga berpendapat:

"Adanya prinsip kedaulatan negara juga menjadi penghalang bagi dewan keamanan untuk melakukan tindakan intervensi terhadap pelanggaran hak asasi manusia yang terjadi dalam suatu negara, namun di sisi lain $\mathrm{PBB}$ sebagai organisasi internasional memiliki kewajiban moral untuk bertindak tegas terhadap pelanggaran hak asasi manusia yang terjadi. Perlu adanya prinsipprinsip universal yang dapat menjadi dasar atas legitimasi intervensi kemanusiaan untuk

This developing international norm in favour of intervention to protect civilians from wholesale slaughter will no doubt continue to pose profound challenges to the international community.". Lihat, Keely, Charles B. (1995). Humanitarian Intervention And Sovereignty. Bereich Forschung und Beratung: Internationale Politik, Sankt Augustin. h. 33 
mendukung penegakan hak asasi, sekaligus sebagai respons atas kondisi dilematis yang dihadapi dalam penegakan hak asasi manusia." 3

Peryataan Kofi Annan di atas secara implisit melahirkan diskursus antara prinsip kedaulatan negara ${ }^{4}$ dan intervensi kemanusian. Secara garis besar dapat dikatakan bahwa prinsip kedaulatan negara dimana negara sebagai pusat legitimasi tidak dapat di intervensi oleh kekuatan apapun secara internasional sedangkan intervensi kemanusian lebih mengedepankan aspek kemanusian dimana negara yang gagal melindungi masyarakatnya di anggap kehilangan legitimasinya. Hadirnya doktrin intervensi kemanusiaan yang diviralkan oleh Hugo Grotius dimana "Berdasarkan "hak" ini, negara dapat mengintervensi secara militer untuk melindungi penduduk atau sebagian penduduknya yang berada dalam suatu

3 Saragih, Santa Merelda. (2018) "Responsibility to Protect: Suatu Tanggung Jawab dalam Kedaulatan Negara". Jurnal Lantera Hukum, 5, (1). h.18

${ }^{4}$ Kedaulatan merupakan konsep yang sangat penting dalam tertib hukum domestik maupun internasional, dan merupakan titik persinggungan antara kedua sistem tertib hukum tersebut. Kedaulatan negara merupakan salah satu norma fondasional dalam sistem hukum internasional. Konsekuensinya, konsep tentang negara yang berdaulat sebagai kesatuan otoritas yang tidak tunduk pada pihak manapun merupakan penyangga sistem tata hukum internasional yang menjunjung tinggi prinsip non-intervensi dan kesepakatan negara lain jika penguasa negara tersebut memperlakukan mereka sedemikian rupa sehingga melanggar hak asasi mereka dan menggoncangkan hati nurani umat manusia."5 Hak tersebut mendorong adanya rekonsepsi makna terhadap prinsip kedaulatan negara sebagai sebuah tanggung jawab untuk melindungi. Perubahan ini menjadi landasan adanya reaktualisasi terhadap paham kedaulatan negara dalam kajian hukum dan hubungan internasional, serta melahirkan legitimasi hukum bagi organisasi internasional terhadap kewajiban pemenuhan hak antara negara dengan organisasi internasional.

\section{Hukum}

kemanusiaan

internasional didasarkan pada kesadaran bahwa konflik merupakan bagian dari sifat dasar manusia yang tidak terelakkan dan tidak dapat dihindari, sehingga diperlukan sebuah pedoman yang mengatur mengenai

(consent) negara. Namun demikian, dalam wacana dan praksis mutakhir konsep kedaulatan negara telah mengalami perubahan; sehingga kedaulatan negara dalam pengertian yang absolut tidak dapat dipertahankan lagi. Lihat, Struet, Michael J. (2006). "The Transformation of State Sovereign Rights and Responsibilities Under the Rome Statute for the International Criminal Court". Chapman Law Review, 8, (1). h. 180

5 Smith, R. K., Asplund, K. D., \& Marzuki, S. (2008). Hukum hak asasi manusia. Pusat Studi Hak Asasi Manusia, Universitas Islam Indonesia (PUSHAM UII). HIm. 21 
hal tersebut. ${ }^{6}$ Lahirnya hukum internasional kemanusian ini tentu saja tidak terlepas dari berbagai perdebatan terkait dengan kedaulatan negara. ${ }^{7}$ Dalam penerapannya hukum internasional kemanusiaan menerapkan prinsip intervensi kemanusiaan. Kedaulatan sendiri dapat di katakan sebagai kekuasaan tertinggi dan bersifat Summa Potestas ${ }^{8}$ yang hanya dimiliki oleh negara. Prinsip ini menegaskan bahwa negara harus mampu melaksanakan kekuasaan yang penuh atau ekslusif atas wilayahnya. ${ }^{9}$ Adanya kedaulatan negara sebagai kekuatan tertinggi menjadi sebuah tantangan terbesar bagi penerapan prinsip intervensi kemanusian.

Semangat organisasi internasional dalam mempromosikan dan memajukan HAM turut diikuti oleh organisasiorganisasi regional. Hal ini dibuktikan dengan hadirnya penerapan konsep HAM regional seperti: Konvensi Eropa tentang

6 Lihat, Boas, Gideon. (2012). Public Internatinal Law (Contemporary Principles and Perspectives). U.K: Edward Elgar. h. 33

7 Menurut Mochtar Kusumaatmadja, kedaulatan negara sebagai kekuasaan tertinggi dibatasi oleh wilayah negara itu sendiri. Hal ini berarti kekuasaan suatu negara terbatas pada wilayah negaranya dan berakhir ketika mencapai batas kedaulatan negara lain. Lihat, Kusumaatmadja, Mochtar dan Agoes, Etty R. (2003) "Pengantar Hukum Internasional". Bandung: P.T. Alumni. H. 16
HAM, Banjul Charter di Kawasan Afrika dan Deklarasi HAM di Amerika Latin dan munculnya deklarasi HAM yang dilakukan oleh Organisasi Islam Internasional sesuai dengan Syariah Islam (Cairo Declaration, 1990).10 ASEAN yang juga merupakan sebuah organisasi regional di kawasan Asia Tenggara namun dalam hal penerapan konsep HAM regional merupakan yang terkebelakang, padahal prinsip dan tujuan yang termaktub di dalam Piagam ASEAN secara jelas mengamanatkan pemajuan dan perlindungan HAM bagi negara-negara anggotanya.

Afrika merupakan salah satu organisasi regional yang dapat dikatakan berhasil dalam menangani permasalahan HAM yang ada di negaranya. Penindasan dan diskriminasi yang dilakukan mendapatkan perlawanan yang akhirnya melahirkan Piagam Banjul.11 Piagam ini yang kemudian menjadi titik balik penanganan dan perlindungan hak asasi

${ }^{8}$. Geenens, Raf. (2016). "E pluribus unum? The Manifold Meanings ofSovereignty". Netherlands Journal of Legal Philosophy, 45 (2). h. 16

9 Adolf, Huala. (2015). Aspek-Aspek Negara dalam Hukum Internasional. Bandung: Keni Media. h. 105

${ }^{10}$ Ibid. h. 3

11 Piagam Banjul (African Charter on Human and Peoples' Rights) merupakan sebuah instrumen HAM internasional bentukan Organisasi Afrika (Organization of African Unity) yang ditujukan untuk mempromosikan serta melindungi kebebasan dan HAM di Afrika. 
manusia di Afrika. Organization of African Unity (OAU) dalam penerapannya pada saat itu mengedepankan prinsip non-intervensi terhadap masalah dari negara-negra anggotanya. Namun, prinsip non-intervensi ini menjadi celah yang akhirnya digunakan oleh para rezim otoriter untuk menindas rakyatnya. Inilah yang menjadi pelopor dibentuknnya Uni Africa (African Union) yang merupakan penerus dari OAU. Berbeda halnya dengan OAU, Uni Africa menekankan tujuan pada perlindungan hak asasi manusia, demokrasi, pembangunan dan ekonomi. ${ }^{12}$ Selain itu, Pasal 4 Piagam Uni Afrika juga menegaskan bahwa Uni Afrika berhak untuk melakukan intervensi jika negara anggotanya melakukan tindakan kejahatan HAM berat yang meliputi, kejahatan perang, genosida dan pelanggaran hak asasi manusia.

ASEAN yang dalam hal ini masih tertinggal jauh dengan organisasi regional lainnya masih terus berupaya

12 Yihdego, Zeray. (2011). "The African Union: Founding Principles, Frameworks and Prospects". European Law Joernal, 17, (5). h. 569

${ }^{13}$ Trisnanto, A. (2012). Eropa dalam Asia: Adopsi atau Imitasi? ASEAN dalam Konteks Integrasi dengan Model Eu. Interaktif, 1(1), 243605.

${ }^{14}$ ASEAN Charter: Preambule ASEAN Charter : "Mematuhi prinsip-prinsip demokrasi, aturan hukum dan tata kepemerintahan yang baik, penghormatan dan perlindungan hak asasi manusia dan kebebasan- kebebasan fundamental"; Tujuan ASEAN angka (7): "memperkuat demokrasi, menghadirkan mekanisme HAM di kawasan Asia Tenggara. Ketertinggalan ini menurut Anggun Trisnanto HS, disebabkan oleh

1. "Secara institusional, respon ASEAN sangat lambat dalam membantu negara-negara anggotanya;

2. Sistem pengambilan keputusan yang sangat incramental dan terlalu birokratis dengan melalui konsultasi informal antar negara anggota terlebih lagi penerapan quite diplomacy ala Asia yang tidak efektif;

3. Penekanan pada proses daripada hasil seringkali menyebabkan masalah tidak terselesaikan secara tuntas."13

Ketentuan menyangkut hak asasi turut dicantumkan di dalam pembukaan, tujuan dan prinsip dari Piagam ASEAN . ${ }^{14}$ Piagam ASEAN juga melalui bab IV pasal 7 mengamanatkan adanya pembentukan badan hak asasi manusia di Kawasan Asia Tenggara. Hal ini menjadi dasar terbentuknya Komisi HAM AntarPemerintah ASEAN (AICHR) ${ }^{15}$.

meningkatkan tata kepemerintahan yang baik dan aturan hukum, dan memajukan serta melindungi hak asasi manusia dan kebebasan-kebebasan fundamental, dengan memperhatikan hak-hak dan kewajiban-kewajiban dari Negara-Negara Anggota ASEAN"; Prinsip ASEAN angka (2) huruf (i) : "menghormati kebebasan fundamental, pemajuan dan perlindungan hak asasi manusia, dan pemajuan keadilan sosial"

${ }^{15}$ AICHR merupakan badan HAM ASEAN yang terbentuk pada tahun 2009 dengan 14 mandat dan 
Kehadiran Komisi HAM AntarPemerintah ASEAN (AICHR) ini ternyata turut mendapat kritik dari berbagai kelompok masyarakat. Kekhawatiran akan terhambatnya fungsi AICHR dalam menangani masalah HAM yang ada dikarenakan adanya prinsip nonintervensi ${ }^{16}$ yang di anut oleh negaranegara di Kawasan Asia Tenggara. Terhitung sampai dengan saat ini AICHR telah menjalankan tugasnya selama hampir 22 tahun, dengan program kerja pertama yakni proses pembelajaran dan pengenalan terhadap anggota ASEAN selama lima tahun (terhitung sejak tahun 2010-1015). Selanjutnya, program kerja AICHR di tahun 2016-2020 yakni mengembangkan hak asasi untuk tercapainya kerja sama bagi ASEAN di bidang hak asasi manusia. ${ }^{17}$

AICHR sebagai satu-satunya komisi hak asasi manusia di ASEAN memiliki fungsi promosi dan perlindungan terhadap hak asasi manusia. Namun, dalam penerapannya AICHR lebih menekankan fungsi promosi dibandingkan fungsi perlindungan. Bukan tanpa alasan, hal ini

fungsi untuk memajukan dan melindungi HAM sesuai dengan Terms of Reference (TOR) AICHR.

16 Prinsip non-intervensi dapat di artikan sebagai kewajiban bagi setiap negara berdaulat untuk tidak mencampuri urusan negara lain. Dalam Pasal 2 Treaty of Amity and Cooperationin Southeast Asia (TAC), menjelaskan bahwa Prinsip fundamental merupakan dasar bagi setiap anggota diakibatan karena adanya prinsip non intervensi yang di ASEAN. Padahal jika melihat permasalahan HAM yang ada dan masih terus terjadi hingga saat ini, terdapat negara-negara yang jelas telah gagal melindungi hak asasi dari masyarakatnya.

Berdasarkan hal itu prinsip non intervensi di ASEAN dan adanya konsep kedaulatan negara serta intervensi kemanusian untuk melindungi menjadi sebuah diskursus dalam penegakan hak asasi manusia di ASEAN.

\section{Rumusan Masalah}

Berdasarkan latar belakang di atas dapat di lihat diskursus non intervensi, kedaulatan negara dan intervensi kemanusian merupakan permasalahan inti penegakan HAM di ASEAN. Oleh karena itu tulisan ini akan membahas mengenai Konsep HAM di ASEAN dan Africa Union Serta keterkaitanya dengan diskursus konsep kedaulatan negara, non intervensi dan intervensi kemanusian di ASEAN.

\section{Metode Penelitian}

Tulisan ini menggunakan metode penelitian hukum normatif dengan

dalam hal menjalin hubungan dengan anggota lainnya: (a)menghormati kebebasan, kedaulatan, kesamaan, kesatuan wilayah dan identitas nasional setiap bangsa; (b)setiap negara memiliki hak untuk mengatur penyelenggaraan negaranya bebas dari intervensi eksternal; (c) adanya prinsip non intervensi dalam hubungan internal sesama anggota ${ }^{17}$ Lihat, Five Year Work Plan ASEAN. 
menggunakan pendekatan perundangundangan; pendekatan konsep dan pendekatan perbandingan. Penelitian hukum normatif merupakan suatu prosedur dan cara penelitian ilmiah untuk menemukan kebenaran berdasarkan logika keilmuan hukum dari segi normatifnya. ${ }^{18}$ Karakter preskriptif ilmu hukum menyebabkan proses penelitian hukum bertujuan untuk menemukan aturan hukum, prinsip hukum, dan doktrin hukum guna menjawab isu hukum yang dihadapi. ${ }^{19}$ Penelitian ini berusaha menggali bahan hukum primer, sekunder, dan tersier dengan harapan dapat memberikan deskripsi serta analisis yang komprehensif.

\section{PEMBAHASAN}

Pelanggaran Hak Asasi Manusia yang terjadi di negara-negara kawasan Asia Tenggara

Permasalahan HAM di kawasan Asia Tenggara menjadi permasalahan yang krusial dan menyita perhatian komunitas Internasional. Upaya yang dilakukan oleh organisasi regional maupun negara yang bersangkutan belum mampu menghilangkan citra gelap ASEAN terkait penegakan HAM. Negara-negara yang memiliki permasalahan pelanggaran hak asasi juga tidak mampu untuk mengatasi permasalahan HAM yang ada di negaranya, hal ini dibuktikan dengan masih terus terjadinya permasalahan pelanggaran HAM di kawasan Asia Tenggara. Adapun beberapa negara ASEAN dengan permasalahan pelanggaran HAM yang tak kunjung selesai di antaranya:

\section{Myanmar}

Keberadaan

Muslim Rohingya sebagai etnis minoritas membuat mereka selalu berada dalam ancaman dan rentan akan penindasan. Global Peace Index 2011 mencatat bahwa Myanmar berada di posisi 133 dari 153 negara yang masuk dalam survei pelanggaran hak asasi manusia. Minority Rights Group juga mengklasifikasikan Myanmar sebagai salah satu dari lima negara teratas yang menjadikan etnis minoritas terus berada dibawah ancaman, sedangakan Freedom House mengkategorikan Myanmar sebagai negara terburuk dari negara-negara yang memiliki catatan hak asasi manusia yang

${ }^{19}$ Marzuki, Peter Mahmud. (2014) Penelitian Hukum. Jakarta: Kencana. h. 59 
buruk. ${ }^{20}$ Laporan ke-45 dewan hak asasi manusia di Jenewa, Swis, Michelle Bachelet selaku Komisaris Tinggi Hak Asasi Manusia menyampaikan bahwa sampai dengan saat ini tidak ada tindakan konkret yang dilakukan oleh pemerintah Myanmar terkait pelanggaran HAM yang terjadi di negara tersebut, haal ini membuat Myanmar di anggap telah gagal memenuhi standar internasional. United Nation Human Rights office of The High Cmissoner pada tanggal 17 September 2020 melaporkan bahwa sampai dengan saat ini ribuan orang di Ronghingya memutuskan meninggalkan rumahnya, dan terdapat 860.000 pengungsi Rohingya di Bangladesh, serta 200.000 orang yang telah mengungsi di Rakhine dan Chin. Lembaga HAM PBB memberikan laporan dampak peningkatan konflik bersenjata di Rohingya termasuk penangkapan sewenang-wenang, penyiksaan,

${ }^{20}$ Sidhu, Jatswan S. Parnini, Syeeda Naushin. (2011) "International Responses to Human Right Violations in Myanmar: The Case of the Rohingya". Journal of International Studies (JIS), 7. h. 119-120

21 Laporan United Nations Human Rights Office of The High Commissioner. (2020). Lihat, pembunuhan ekstra yudsial dan penghacuran properti sipil yang mengakibatkan meningkatnya korban sipil. ${ }^{21}$

Tiga tahun telah berlalu sejak terjadinya genosida di Rohingya, namun sampai dengan saat ini tidak ada keadilan apalgi penegakan HAM bagi para etnis muslim Rohingya. Khin Omar, sebagai ketua dari organisasi HAM Myanmar, mendesak agar masyarakat internasional merujuk Myanmar ke Pengadilan Kriminal Internasional (ICC) atau membentuk pengadilan ad-hoc, dengan tujuan untuk meminta pertanggungjawaban pidana atas genosida terhadap Rohingya, kejahatan kemanusiaan dan kejahatan perang terhadap etnis minoritas lainnya. ${ }^{22}$

\section{Thailand}

$$
\begin{aligned}
& \text { Permasalahan pelanggaran } \\
& \text { HAM juga terjadi di Thailand, } \\
& \text { kurangnya tenaga kerja } \\
& \text { berketerampilan rendah di }
\end{aligned}
$$

https://www.ohchr.org/EN/NewsEvents/Pages/M yanmar ReportDetails.aspx (diakses pada 10 September 2020).

22 Ibid 
Thailand membuat Thailand meminta para pekerja migran dari negara lain. Meskipun Thailand memiliki lembaga legal yang mengurus penerbitan izin kerja para pekerja migran di negara tersebut, namun tidak sedikit pekerja migran di Thailand yang dipekerjakan secara Ilegal. Pada tahun 2008, sekitar 1,3 juta pekerja migran di Thailand direkrut dengan cara Ilegal. Status Ilegal para pekerja serta kurangnya pemahaman terkait hukum di Thailand ditambah rasa takut akan di deportasi membuat para pekerja migran di Thailand sering di eksploitasi dan harus menerima pelecehan dari para majikan, polisi bahkan pejabat pemerintah tanpa bisa melakukan apapun. ${ }^{23}$

Diferensiasi ASEAN dan Uni Afrika dalam Menangani Pelanggaran Hak Asasi Manusia

1. ASEAN

Pasal (1) Piagam ASEAN menyatakan bahwa ASEAN bertujuan untuk memelihara dan meningkatkan perdamaian, keamanan, dan stabilitas serta lebih memperkuat nilai-nilai yang berorientasi pada perdamaian di kawasan Asia Tenggara. Penegasan terhadap penghormatan hak asasi manusia yang tertuang dalam Piagam ASEAN haruslah menjadi spirit bagi ASEAN untuk secara tegas menangani pelanggaran hak asasi manusia yang terjadi di negara kawasan Asia Tenggara. Upaya pemajuan dan perlindungan HAM di kawasan ASEAN merupakan komitmen bersama seluruh anggota ASEAN yang kemudian diwujudkan dalam pembentukan AICHR, sebagaimana mandat dari pasal 14 Piagam ASEAN. Sejak awal terbentuknya AICHR terus didorong untuk terus maju dalam upaya memenuhi mandat pemajuan dan perlindungan HAM di kawasan Asia Tenggara.
23 Gunawan, Yordan. Elven, Tareq Muhammad Aziz (ed). (2017). "The Urgensi of ASEAN Human Rights Court Establishment to Protect Human Rights Ini Souteast Asia". Dalam
PROCEEDING International Conference on Law and Society, LP3M \& Faculty of Law Universitas Muhammadiyah Yogyakarta. h. 9 
AICHR memiliki 14 mandat

dan fungsi, yakni untuk: ${ }^{24}$

Mengembangkan strategi untuk promosi dan perlindungan hak asasi

manusia

Mengembangkan Deklarasi HAM untuk membangun kerngka kerja sama hak asasi manusia melalui berbagai konvensi ASEAN dan instrumen HAM lainnya (3) Meningkatkan kesadaran publik tentang hak asasi manusia melaui pendidikan, penelitian dan penyebaran informasi

Mempromosikan peningkatan kapasitas guna tercapainya efektivitas dari perjanjian hak asasi manusia internasional oleh anggota ASEAN (5) Mendorong negara-negara anggota ASEAN untuk mempertimbangkan dan meratifikasi instrumen hak asasi manusia internasional

Mempromosikan pelaksanaan instrumen ASEAN yang terkait dengan hak asasi manusia (7) Memberikan layanan konsultasi dan bantuan teknis terkait HAM (8) Terlibat dalam dialog dan konsultasi dengan ASEAN (9) Berkonsultasi terkait dengan promosi dan perlindungan HAM (10) Untuk memperoleh informasi dari Negara Anggota ASEAN tentang promosi dan perlindungan ASEAN (11) Mengembangkan pendekatan terhadap kepentingan ASEAN (12) Mempersiapkan kajian terkait isu-isu hak asasi manusia di ASEAN

Menyampaikan laporan tahunan tentang kegiatan atau laporan lainnya (14) Melakukan tugas yang ditugaskan padanya.

Jika kita melihat 14 mandat di atas terlihat mandat dari AICHR sangat terbatas, dalam poin 1,6 dan 9 serta sebagain poin yang lain terlihat fungsi AICHR hanya terbatas pada bidang promosi dan tugas-tugas normatif lainnya akan tetapi mandat AICHR masih memberikan ruang untuk penegakan HAM di ASEAN. Hal ini terlihat dari nomenklatur pada poin 2, 5 dan 12 yang mendorong dan mengembangkan HAM di ASEAN agar lebih efektif dengan 
cara bekerjasama dengan komunitas internasional, meratifikasi instrumen HAM dan melakukan kajian kontemporer mengenai isu-isu strategis tentang HAM. Oleh karena itu jika melihat argumentasi di atas dapat di katakan bahwa AICHR dapat memperluas mandat atau wewenangnya dalam perlindungan dan penegakan HAM di ASEAN. Terlepas dari itu penting untuk mempertimbangkan keputusan negara-negara anggota untuk perlindungan dan penegakan HAM di ASEAN, karena prinsip non intervensi yang masih di pertahankan dalam piagam ASEAN menjadikan AICHR sebagai komisi promosi HAM bukan sebagai komisi perlindungan dan penegakan HAM di ASEAN.

Harapan ASEAN terhadap pembentukan AICHR sendiri sebagaimana dimuat dalam TOR AICHR pasal 1 adalah merealisasikan tujuan ASEAN. Namun, sampai dengan saat ini AICHR masih belum mengoptimalkan fungsi perlindungan yang dimilikinya.
Selain terbatas pada isi mandat yang memang menekankan pada fungsi promosi, AICHR juga terus dibatasi dengan keberadaan prinsip non intervensi yang diterapkan oleh ASEAN. Selain itu, pembahasan permasalahan HAM yang seharusnya dilakukan oleh AICHR tidak dapat dilaksanakan tanpa adanya kesepakatan dari semua negara anggota AICHR. Mekanisme yang mengharuskan setiap permasalahan yang akan diangkat ke sidang AICHR harus terlebih dahulu dibahas bersama oleh pimpinan ASEAN dan seluruh negara anggotanya, menjadi bukti kurangnya sikap independent dari AICHR dalam upaya penegakan HAM ASEAN. Penguatan mandat AICHR merupakan langkah penting yang harus dilakukan untuk mendukung visi ASEAN yakni "putting people first".

\section{African Union}

Organisasi Afrika yang dibentuk pada tahun 1963, pada awalnya tidak memprioritaskan hak asasi manusia, terbukti dengan tidak adanya pembahasan secara eksplisit terkait hak asasi manusia 
dalam setiap kententuan yang ada dalam Piagam Organisasi tersebut. Baru, pada tahun 1981 negaranegara anggota mengesahkan Piagam Africa tentang hak asasi manusia dan rakyat, yang berfungsi sebagai perjanjian hak asasi manusia pertama yang mengikat secara hukum. Piagam tersebut juga mengamanatkan Komisi HAM Africa, yang kemudian dibentuk enam tahun setelah pengesahan dokumen pada tahun 1987.25 Komisi HAM Africa (ACHPR) memiliki fungsi promosi dan perlindungan terhadap hak asasi manusia. ACHPR memiliki kewenangan untuk melakukan investigasi serta mengembangkan aturan untuk menyelesaikan masalah hukum terkait dengan perlindungan hak asasi manusia, namun ACHPR tidak diberikan kewenangan untuk menghukum pelanggar hak asasi manusia. ${ }^{26}$ Keterbatasan ACHPR terkait sumber dayanya serta

${ }^{25}$ Sarkin, Jeremy. (2009). "The Role of The United Nations, the African Union and Africa's Sub Regional Organization in Dealing with Africa's Human Rights Problem: Connecting Humanitarian Intervention and Responsibility to Protect". Journal of African Law, 53, (1). h. 7 ketidakberhasilan ACHPR dalam melaporkan situasi HAM dari negara anggota membuat ACHPR dapat dikategorikan sebagai badan yang tidak efektif.

Perkembangan

permasalahan HAM di afrika melahirkan pengadilan HAM afrika yang didirikan berdasarkan Pasal 1 dari Protokol Piagam Afrika tentang Hak Asasi Manusia dan Rakyat tentang Pembentukan Pengadilan Afrika tentang Hak Asasi Manusia dan Rakyat yang diadopsi oleh Negara Anggota dari Organisasi tersebut. dari OAU, pada bulan Juni 1998. Protokol mulai berlaku pada tanggal 25 Januari 2004.27 Pengadilan ini sendiri mempunyai mandat yaitu: "untuk meningkatkan mandat perlindungan Komisi Afrika untuk Hak Asasi Manusia dan Hak Rakyat dengan memperkuat sistem perlindungan hak asasi manusia di Afrika dan memastikan penghormatan dan kepatuhan terhadap Piagam Afrika tentang Hak Asasi Manusia dan Rakyat,

${ }^{26}$ Lihat, African Charter ond Human and and People Rights.

27 Lihat, Terms of References of ASEAN Intergovernmental Commission On Humam Rights Lihat, https://www.african-court.org/en/ (diakses Tanggal 7 Oktober 2020). 
serta instrumen hak asasi manusia internasional lainnya, melalui keputusan yudisial"

Pengadilan HAM Afrika sendiri mempunyai fungsi yudisial yang di atur dalam Protocol (Article 5) dan Rules (Rule 33) yang menyatakan bahwa:

"the Court may accept complaints and / or applications submitted to it by either the Commission on Human and African Peoples' Rights or States parties to the Protocol or African Intergovernmental Organizations"

Berdasarkan penjelasan di atas dapat di katakan bahwa wilayah afrika telah mengalami kemajuan yang sangat pesat dalam aspek penegakan dan perlidungan HAM. Hal ini dapat di lihat dari mandat dan Protocol (Article 5) dan Rules (Rule 33) yang menegaskan fungsi yudisial dari pengadilan HAM Afrika.

Pengadilan HAM Afrika bertanggung jawab terhadap

${ }^{28}$ Organization of African Unity (OAU) yang di gantikan African Union (AU) pada tanggal 9 juli 2002 di sebabkan OAU di anggap gagal untuk menghentikan konflik internal di negara-negara anggota serta meluasnya pelanggaran hak asasi manusia yang terjadi termasuk banyaknya rezim otoriter yang melakukan pelanggaran HAM yaitu pelanggaran hak asasi manusia yang dilakukan oleh negara-negara yang berada di bawah yurisdiksinya, serta memiliki kekuasaaan untuk mengeluarkan putusan yang mengikat secara hukum terhadap negara anggota yang melanggar hak asasi manusia dan mengharuskan mereka untuk memberikan kompensasi atau restitusi kepada korban. Walupun demikian, Pengadilan Afrika yang berdiri saat itu tidak dapat mengenyampingkan hukum domestik negara-negara anggota. Baru setelah Organization of African Unity ("OAU").diteruskan oleh African Union (AU), ${ }^{28}$ prinsip non-intervensi yang sebelumnya termaktub di dalam Piagam OAU tidak lagi diterapkan secara kaku, hal ini terbukti dengan hadirnya ketentuan yang dimuat dalam Piagam AU yang memberikan ruang bagi organisasi ini untuk

rezim Idi Amin di Uganda dan Jean-Bédel Bokassa di Republik Afrika Tengah. Lihat, Sharpe, Marina. (2017). From Non-Interference to NonIndifference:The African Union and the Responsibilityto Protect. Uganda: International Refugee Rights Initiative. h. 10 
dapat melakukan intervensi ${ }^{29}$ terhadap negara anggotanya yang melakukan pelanggaran tindakan kejahatan HAM berat.

Berkaitan dengan itu African Union sendiri telah merevisi isi piagamnya dengan menghapus ketentuan Non Intervensi. Hal ini di sebabkan adannya kegagalan masa lalu dari OAU dalam melindungi dan penegakan HAM di wilayah afrika, karena terbatasnya mandat serta adanya prinsip Non intervensi. Selain itu dalam perkembangannya AU telah merevisi prinsip-prinsip Piagam OAU yang sebelumnya karena dianggap menjadi penghalang utama dari perkembangan sosial, perdamaian dan keamanan di antara negara-negara anggotanya. Hal ini lebih lanjut diikuti dengan adanya prinsip sebagaimana yang tertuang dalam Pasal 4 (h) African Union Constitutive Act Provides yakni mengakui bahwa AU memiliki hak untuk campur tangan terhadap suatu negara anggota, jika terjadi suatu keadaan darurat

${ }^{29}$ Article 4(h) of the African Union ("AU") Constitutive Act provides that the $\mathrm{AU}$ has the right to intervene in a member state in "grave seperti: adanya tindakan kejahatan perang, genosida dan kejahatan terhadap kemanusiaan, serta negara anggota juga memiliki hak untuk meminta intervensi dari organisasi untuk tujuan memulihkan perdamaian dan keamanan negara.

Jika melihat diferensiasi antara ASEAN dan Africa Union terlihat jelas dalam aspek perlindungan dan penegakan HAM Africa union menjadi organisasi regional yang berperan penting terlepas dari persamaan bahwa kedua organisasi regional ini bertugas untuk mempromosikan perlindungan dan penegakan HAM akan tetapi ASEAN sendiri belum mempunyai mekanisme yudusial. Selain itu prinsip non intervensi ASEAN masih menjadi hambatan terbesar untuk perlindungan dan penegakan HAM di ASEAN. Prinsip non intervensi yang diterapkan sudah seharusnya tidak lagi diterapkan secara kaku. Oleh karena itu penting adanya reformasi dalam organisasi ASEAN seperti yang telah di lakukan oleh Afrika Union dengan melakukan keputusan politis atas dasar urgensi perlindungan dan penegakan HAM di ASEAN sehingga apa

circumstances, namely, war crimes, genocide, and crimes against humanity." 
yang menjadi visi serta tujuan ASEAN dapat diimplementasikan secara optimal. Untuk lebih jelasnya dapat di lihat di tabel berikut:

\section{Bagan 1}

Diferensiasi Pengaturan dan Konsep HAM ASEAN DAN AFRICA UNION
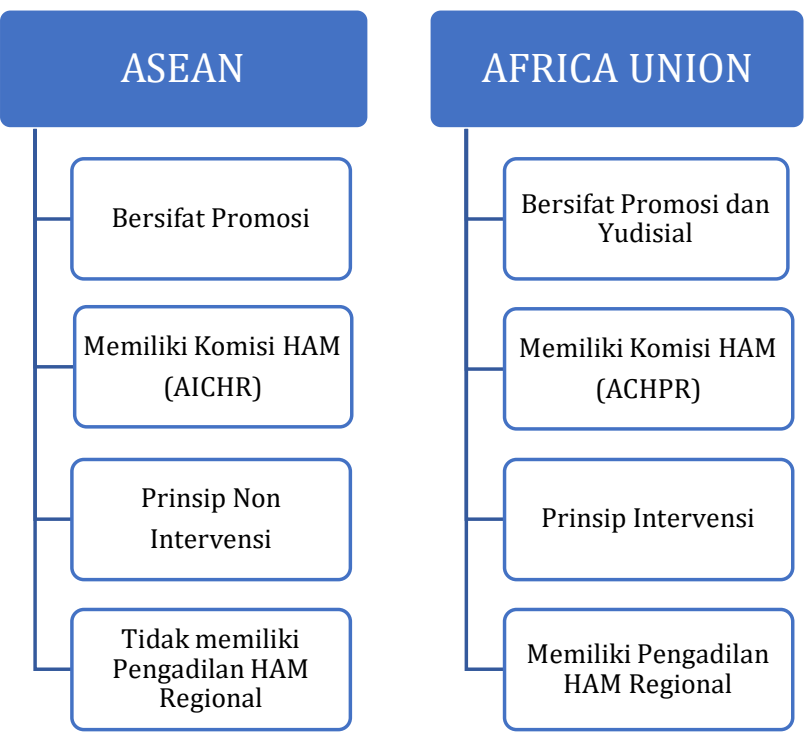

\section{Diskursus Kedaulatan Negara, Non} Intervensi dan Intervensi Kemanusian dalam Penagakan HAM di ASEAN

Teori Kedaulatan Negara oleh Jean Bodin mendalilkan bahwa Negara memiliki kekuasaan untuk membuat dan melaksanakan hukum atas wilayah dan/atau yurisdiksinya. Pelaksanaan hukum tersebut bersifat tetap, asli, bulat dan tidak terbatas dalam konteks internal dan eksternal.“Makna kedaulatan eksternal menurut Teori Kedaulatan Negara dikembangkan kontekstualitasnya oleh
Andrew Altman dan Christopher Heath Wellman. Menurut teori mereka, kedaulatan negara masih relevan dengan sistem hukum Hukum Internasional saat ini dan saat yang akan datang. Mereka memperluas konteks hubungan hukum antara negara dengan warga negaranya terhadap eksistensi norma internasional yang memengaruhi yurisdiksi hukum suatu negara terkait dengan munculnya intervensi kemanusiaan dan kewajiban untuk melindungi dalam khazanah hukum internasional dan dalam hubungan internasional. ${ }^{30}$

Penekanan pada larangan kekerasan dalam Piagam PBB mengarah pada aspek kedaulatan negara dapat di katakan bahwa Non Intervensi adalah aspek terpenting dalam kedaulatan negara, dan berhubungan erat dengan hubungan internasional. Meningkatnya penerimaan prinsip intervensi kemanusiaan mengakibatkan prinsip kedaulatan negara mengalami perubahan dalam perkembangan hukum internasional kontemporer. Sebaliknya, intervensi kemanusiaan mengubah konsep dan praktek kedaulatan Negara dengan fakta bahwa persyaratan non intervensi dalam

International Justice. Oxford: Oxford University Press. h. 45 
perkembanganya dapat di kesampingkan untuk melindungi masyarakat. Sejak Piagam PBB disahkan, dapat di katakan bahwa konsep kedaulatan Negara telah berubah $^{31}$ hal ini karenakan perilaku negara dalam melindungi warganya sendiri, memerangi Terorisme dalam perang dan perang saudara, dll. Telah menghasilkan perubahan dalam konsep kedaulatan negara dalam Piagam PBB yang didefinisikan sebagau ius ad bellum. Untuk perubahan definisi yang sedang berlangsung yaitu konsep kedaulatan konkret yang dapat di artikan bahwa kedaulatan negara merupakan kewajiban untuk melindungi masyarakat dari pelanggaran HAM. ${ }^{32}$ Oleh karena itu dapat di katakan bahwa legitimasi kedaulatan negara adalah sejauhmana negara dapat melindungi rakyatnya.

Perubahan ataupun pengurangan konsep kedaulatan sebenarnya sudah mulai terjadi sejak akhir abad ke-19 dan awal abad ke-20, di mana kontroversi tentang konsep absolute dan indivisible dari

31 Oppenheim dalam pandanganya mengatakan bahwa "There exists perhaps no conception the meaning of which is more controversial than that of sovereignty. It is an indisputable fact that this conception, from the moment when it was introduced into political science until the present day, has never had a meaning which was universally agreed upon." Lihat, Nagan, Winston P. Hammer, Craig. (2004). "The Changing Character pf Soveriignty in Internasional Law and International kedaulatan ini perlahan-lahan mulai tenggelam." Sejak Treaty of Westphalia yang memunculkan prinsip integritas teritorial di mana kedaulatan diinterpretasikan sebagai kapasitas hukum yang menempatkan kewenangan negara di atas semua kewenangan hukum di luar negara. Perubahan paradigma tentang kedaulatan negara tidak pernah berhenti dikarenakan faktor-faktor yang telah dikemukakan sebelumnya. Hal tersebut ditambah dengan fase Perang Dunia II dan pembentukan, perkembangan, serta peran United Nations untuk kepentingan bersama semua negara. Kekuatan absolut yang diklaim oleh negara berdaulat kini harus berhadapan dengan keberadaan organisasi internasional dan inter-governmental bodies lain yang mendukung adanya sebuah collective action dan state accountability to an international community," dan menciptakan erosi paradigma kedaulatan yang sangat besar. ${ }^{33}$

Relations". Colombia Journal of Transnational Law, 43, (1). h. 1

${ }^{32}$ Keely, Charles B. (1995). Humanitarian Intervention And Sovereignty. Bereich Forschung und Beratung: Internationale Politik , Sankt Augustin. h. 2

${ }^{33}$ Deng, Francis M. (2010) "From Sovereignty as Responsibility' to the Responsibility to Protect". Global Responsibility to Protect, 2, (1). h. 354 
Dari perspektif politik internasional, sensitivitas intervensi kemanusiaan dan kedaulatan negara serta non intervensi muncul karena dua hal utama. Pertama, dilakukan dengan penggunaan kekerasan (use offorce) yang dalam aspek legal, sangat tidak dibenarkan. Kedua, intervensi kemanusiaan dijalankan dengan cara melanggar kedaulatan negara dan prinsip non intervensi yang diintervensi. Dimensi terakhir ini lebih peka daripada yang pertama karena dengan politik internasional, masalah kedaulatan (sovereignty) berada di atas segalanya. Aspek kedaulatan inilah yang membuat sebuah negara atau bangsa dianggap bermartabat. Itulah sebabnya, tiap intervensi terjadi, apakah itu intervensi karena alasan balasan, pembelaan diri ataukah intervensi kemanusiaan, semua disorot dan dinilai dengan pertimbangan kedaulatan negara. ${ }^{34}$

$$
\text { Dalam Pasal } 2 \text { (4) Piagam }
$$

Perserikatan Bangsa-Bangsa menyatakan bahwa:

"All Members shall refrain in their interna-tional relations from the threat or use of forceagainst the territorial integrity or political independence of any state, or in any other mannerinconsistent with the Purposes of the UnitedNations."

Ketentuan di atas menekankan bahwa setiap pelaksanaan hubungan internasional yang dilakukan oleh negara anggota PBB dengan negara lainnya, tidak boleh menggunakan kekerasan yang dapat mengancam integritas wilayah negara atau kemerdekaan politik negara manapun, atau menggunakan cara yang tidak sesuai dengan tujuan PBB.

Dalam Pasal 2 (7(a)) Piagam Perserikatan Bangsa-Bangsa menyatakan bahwa:

"Nothing contained in the present Chartershall authorize the United Nations to intervene inmatters which are essentially within the domesticjurisdiction of any state or shall require the Mem-bers to submit such matters to settlement underthe present Charter"

Ketentuan di atas menyatakan bahwa tidak satupun ketentuan dalam piagam ini yang memberikan wewenang kepada suatu negara maupun PBB untuk melakukan intervensi terhadap masalah dalam yurisdiksi negara lain. Hal ini yang kemudian menjadi dasar berlakunya prinsip non intervensi dalam Hukum Internasional. Kehadiran prinsip non 
intervensi ini tentu saja memberikan kedaulatan penuh terhadap suatu negara untuk mengatur sendiri segala ketentuan yang terkait dengan negaranya.

Kedaulatan negara yang bersifat summa postestas sering berujung pada penyalahgunaan kewenangan oleh otoritas negara yang berakhir pada tidak terpenuhinya hak-hak dasar dari warga negaranya, bahkan sampai mengakibatkan terjadinya pelanggaran HAM berat seperti kejahatan perang, pembersihan etinis, kejahatan kemanusiaan dan genosida. Ketika negara yang bersangkutan kehilangan legitimasi dan dianggap tidak mampu untuk mempertanggung-jawabkan kewajibannya untuk melindungi, menjamin dan memenuhi HAM dari warganya, maka keikutsertaan pihak lain merupakan urgensi untuk dapat membantu dan menangani permasalahan HAM tersebut. Adapun bentuk keikutsertaan yang di maksud dapat berupa intervensi militer maupun intervensi kemanusiaan.

Doktrin intervensi kemanusiaan dapat dilihat pada ketentuan bab VII dari piagam PBB. Isi dari bab VII piagam PBB menjelaskan bahwa Dewan Keamanan (DK) PBB memiliki kewajiban untuk memelihara perdamaian. Dalam Pasal 41 Piagam PBB menyatakan:

"Should the Security Council consider that meas-ures provided for in Article 41 would be inadequate or have proved to be inadequate, it may takesuch action by air, sea, or land forces as may benecessary to maintain or restore internationalpeace and security. Such action may includedemonstrations, blockade, and other operationsby air, sea, or land forces of Members of the UnitedNation."

ketentuan ini memberikan wewenang kepada DK PBB untuk mengambil tindakan yang diperlukan jika ketetentuan yang diatur dalam pasal $41^{35}$ Piagam PBB terbukti tidak efektif termaksud melakukan ingtervensi yurisdiksi negara tanpa perlu menunggu adanya permintaan dari negara tersebut. Sehingga berdasarkan ketentuan tersebut DK PBB berhak menetukan terkait adanya ancaman perdamaian, pelanggaran perdamaian atau adanya tindakan agresi oleh suatu negara tertentu, sehingga berdasarkan situasi tersebut DK PBB dapat mengambil tindakan militer maupun nonmiliter dengan tujuan memulihkan perdamaian dan keamanan nasional. Sehingga setiap tindakan yang dilakukan suatu negara terhadap yurisdiksi negara lain 
berdasarkan mandat dari Dewan Keamanaan (DK) PBB yang keputusannya didasarkan sesuai ketentuan yang diatur dalam bab VII Piagam PBB, bukan merupakan pelanggaran terhadap prinsip non intervensi.

Arend dan Beck sendiri berpendapat 4 Kriteria intervensi dapat di lakukan yaitu: ${ }^{36}$

"First, there must be within the target country a "direct and extensive threat to human rights, in particular the threat of widespread loss of human life." Second, the specific objectives of intervention should be fundamentally limited to protecting human rights. Third, coercive action must not be carried out based on the invitation of the legitimate government of the target status or carried out with the explicit consent of the country. Fourth, in fact, "humanitarian intervention" alone authorization of the Security Council"

Berdasarkan pendapat Arend dan Beck dapat di pahami bahwa Kriteria pertama dan kedua, bagaimanapun, menetapkan standar yang tinggi dan mungkin tidak dapat dijangkau. Hal ini di karenakan intervensi tidak dapat dilakukan untuk alasan penting selain untuk tujuan kemanusiaan. Walapun tidak ada ukuran cannot be undertaken with the

yang pasti tentang skala pelanggaran HAM yang di lakukan. Kriteria tiga dan empat pada dasarnya membatasi intervensi pada tindakan yang dilakukan tanpa otorisasi/persetujuan oleh negara target atau di bawah Piagam PBB. Kondisi pertama menunjukkan pelanggaran harus meluas dan bahkan menuntut hilangnya nyawa sebagai alasan yang dapat dibenarkan

Prinsip non-intervensi merupakan dasar bagi ASEAN dalam menjalankan hubungan antar sesama anggota ASEAN. Keberadaan prinsip ini dianggap paling efektif untuk mencegah dan meminimalisasi terjadinya konflik di kawasan ASEAN. Namun, keberadaan prinsip non-intervensi juga menjadi hambatan terbesar bagi ASEAN untuk memaksimalkan perannya dalam penyelesaian konflik yang terjadi di negara-negara anggotanya. ${ }^{37}$

ASEAN sebagai komunitas regional yang menganut nilai-nilai universal, kekeluargaan dan kepedulian satu samalain, yang di bentuk berdasarkan keinginan untuk saling bekerjasama dan membantu antar sesama anggota menjadi paradox ketika pelanggaran HAM yang

${ }^{36}$ Keely, Charles B. Op. cit, hlm. 17
${ }^{37}$ Rahmanto, Tony Yuri. (2017). "Prinsip NonIntervensi bagi ASEAN ditinjau dari Perspektif Hak Asasi Manusi". Jurnal HAM, 8, (2). h. 150 
dilakukan oleh negara anggota ASEAN tidak dapat diatasi. Permasalahan ini yang menjadikan penafsiran ganda ASEAN dalam memandang pelanggaran HAM yang terjadi di regional. Hal ini sekaligus menjadi bukti bahwa ASEAN hanya komunitas formal dan tempat diskusi negara anggota tanpa mempunyai mekanisme yang jelas dalam perlindungan HAM.

ASEAN sebagai organisasi regional di bagian bumi selatan nampaknya masih jauh tertinggal bahkan dengan negaranegara Afrika, dimana africa union telah melakukan pembaharuan dalam aspekaspek penegakan dan perlindungan HAM. Hal ini dapat di buktikan dengan komitmen negara-negara anggota untuk menjunjung tinggi prinsip HAM dari pada aspek kedaulatan negara dan non-intervensi walaupun dalam prakteknya masih banyak kasus pelanggaran HAM di kawasan afrika, seperti di libya, daftur, afrika tengah dan beberapa negara lainya tetapi secara normatif africa union berhasil menjadi salah satu organisasi regional yang mendukung ekosistem HAM. Jika melihat ASEAN dengan beberapa pelanggran HAM seperti yang terjadi di Myanmar dan Thailand, dapat di katakan ASEAN gagal untuk menjalankan fungsinya dalam aspek perlindungan HAM dengan dalil kedaulatan negara dan non- intevensi ASEAN secara terang membirkan pelanggaran HAM terjadi di negara-negara anggotanya

Paradox ASEAN tentang kedaulatan negara, non intervensi dan intervensi kemanusian" perlu disikapi secara serius oleh negara-negara di ASEAN untuk mendukung kawasan yang aman dan damai. Negara anggota ASEAN harus melihat aspek yang lebih jelas tentang batasan-batasan dan prinsip universal kemanusian secara umum di katakan bahwa pinsip kedaulatan negara dan non intervensi mempunyai kedudukan legal dalam kerangka piagam ASEAN akan tetapi moralitas dan kemanusian perlu di pertimbangkan begitupula dengan konsep prinsip non-intervensi bahwa sebuah intervensi terhadap urusan internal negara lain adalah dilarang. Sedangkan pelanggaran HAM adalah hal yang berbeda. Interpretasi secara subjektif terhadap intervensi kemanusiaan dalam prinsip nonintervensi yang berpendapat bahwa intervensi kemanusian melanggar kedaulatan suatu negara merupakan alasan politis.

Komitmen pembentukan komunitas ASEAN yang mengedepankan tanggung jawab bersama dalam hal keamanan, stabilitas dan perdamaian. Sudah 
seharusnya negara-negara ASEAN melihat pelanggaran HAM di Myanmar dan Thailand. Meskipun ASEAN sudah membentuk AICHR pada tahun 2009, namun komitmen antar negara masih menjadi perdebatan sehingga peranan AICHR hanya terbatas.

Berdasarkan hal tersebut penulis berpendapat ada tiga upaya yang harus di lakukan untuk perlindungan dan penegakan HAM di ASEAN yaitu:

1. ASEAN yang menjunjung tinggi rasa kebersamaan dan kekeluargaan dalam mengatasi permasalahan HAM negara anggota harus mengupayakan cara-cara damai dengan melakukan pertemuan antar negara anggota. Hal ini di maksudkan agar penyelesain permasalahan HAM di dasarkan atas kemufakatan.

2. ASEAN perlu melakukan peninjau kembali prinsip kedaulatan negara dan non intervensi dengan melihat perkembangan hukum internasional kontemporer. Negara ASEAN perlu membuat komitmen bahwa intervensi kemanusian dapat di lakukan sebagai langkah terakhir jika tidak ada penyelesain HAM antar negara anggota. Selain itu
ASEAN sendiri perlu untuk memberikan indikator/batasan mengenai mengapa, kapan dan bagaimana intervensi kemanusian dapat di lakukan. Hal ini di lakukan agar intervensi kemanusian di lakukan untuk tujuan damai bukan untuk tujuan politis atau pergantian rezim.

3. ASEAN perlu berkomitmen penuh terhadap AICHR guna mendukung ekosistem perlindungan dan penegakan HAM di asean. Hal ini dapat dilakukan dengan merevisi beberapa mandar AICHR agar AICHR bukan hanya bekerja dalam aspek promosi tetapi memiliki fungsi legal dan berkomitmen untuk memenuhi beberapa mandat AICHR seperti Mengembangkan Deklarasi HAM untuk membangun kerangka kerja sama hak asasi manusia melalui berbagai konvensi ASEAN dan instrumen HAM lainnya, Mendorong negara-negara anggota ASEAN untuk mempertimbangkan dan meratifikasi instrumen hak asasi manusia internasional, dan bahkan menurut Kuntjoro Purbopranoto, "konstitusikonstitusi negara harus mengadopsi 
prinsip-prinsip perlindungan hak asasi manusia." 38

\section{PENUTUP}

ASEAN sebagai organisasi regional dianggap belum mampu memaksimalkan fungsi dan tujuannya sebagaimana isi dari Piagam ASEAN. Keberadaan prinsip nonintervensi serta tidak optimalnya fungsi AICHR dalam upaya pemajuan dan penegakan HAM menjadi hambatan terbesar bagi ASEAN. Permasalahan serupa juga terjadi di Afrika Union namun dalam perkembangan HAM kontemporer Uni Afrika telah melakukan pembaharuan ketentuan dan mekanisme yang dianggap menjadi hambatan bagi pemajuan dan penegakan HAM di kawasannya. Penerapan prinsip non-intervensi tidak lagi di jalankan secara statis, keberadaan prinsip kedaulatan negara tetap di terapkan namun terkait permasalahan kemanusian African Union berhak untuk turut campur, sebagaimana ketentuan dalam Africa Union Constitutive Act yang berlaku bagi setiap negara anggota yang melakukan melakukan pelanggaran HAM. Diskursus penegakan HAM ASEAN dan Uni Afrika

38 Puluhulawa, M.R.U dan Jufryanto Puluhulawa. (2020) Implikasi Pasal $28 F$ Undang-Undang Dasar Republik Indonesia 1945 Terhadap Fenomena HOAKS dapat menjadi tolak ukur bagi ASEAN untuk melakukan pembaharuan guna mewujudkan perlindungan dan penegakan HAM dia kawasan Asia Tenggara.

\section{REFERENSI}

\section{Buku}

Adolf, Huala. (2015). Aspek-Aspek Negara dalam Hukum Internasional. Bandung: Keni Media.

Altman, Andrew. Wellman, Christopher Heat. (2011). A Liberal Theory of International Justice. Oxford: Oxford University Press.

Awaludin, Hamid. (2012). HAM, Politik, Hukum dan Kemunafikan Internasional. Jakarta:PT Kompas Media Nusantara.

Baldini, Stefania. Ravasi, Guido (ed). (2000). Humanitarian Action And State Sovereignty. Edizioni Nagard: Dragan European Foundation.

Boas, Gideon. (2012). Public Internatinal Law (Contemporary Principles and Perspectives). U.K: Edward Elgar. Gunawan, Yordan. Elven, Tareq Muhammad Aziz (ed). (2017) "The

di Era Digital. Jurnal Majelis : Media Aspirasi Konstitusi, 8. HIm. 191-212 
Urgensi of ASEAN Human Rights Court Establishment to Protect Human Rights Ini Souteast Asia". Dalam PROCEEDING International Conference on Law and Society, LP3M \& Faculty of Law Universitas Muhammadiyah Yogyakarta.

Keely, Charles B. (1995). Humanitarian Intervention And Sovereignty. Bereich Forschung und Beratung: Internationale Politik , Sankt Augustin.

Kusumaatmadja, Mochtar dan Agoes, Etty R. (2003) "Pengantar Hukum Internasional”. Bandung: P.T. Alumni. Marzuki, Peter Mahmud. (2014) Penelitian Hukum. Jakarta: Kencana.

Sharpe, Marina. (2017). From NonInterference to Non-Indifference:The African Union and the Responsibilityto Protect. Uganda: International Refugee Rights Initiative.

Smith, R. K., Asplund, K. D., \& Marzuki, S. (2008). Hukum hak asasi manusia. Pusat Studi Hak Asasi Manusia, Universitas Islam Indonesia (PUSHAM UII).

Ibrahim, Johnny. (2006). Teori dan Metodologi Penelitian Hukum Normatif. Malang: Bayu Media Publishing.

\section{Jurnal}

Deng, Francis M. (2010) “From Sovereignty as Responsibility' to the Responsibility to Protect". Global Responsibility to Protect, 2, (1).

Geenens, Raf. (2016). "E pluribus unum? The Manifold Meanings ofSovereignty". Netherlands Journal of Legal Philosophy, 45 (2).

Nagan, Winston P. Hammer, Craig. (2004). "The Changing Character pf Soveriignty in Internasional Law and International Relations". Colombia Journal of Transnational Law, 43, (1). Puluhulawa, M.R.U dan Jufryanto Puluhulawa. (2020) "Implikasi Pasal 28F Undang-Undang Dasar Republik Indonesia 1945 Terhadap Fenomena HOAKS di Era Digital.” Jurnal Majelis : Media Aspirasi Konstitusi, Jilid 8.

Rahmanto, Tony Yuri. (2017). "Prinsip NonIntervensi bagi ASEAN ditinjau dari Perspektif Hak Asasi Manusi”. Jurnal HAM, 8, (2).

Sidhu, Jatswan S. Parnini, Syeeda Naushin. (2011) "International Responses to Human Right Violations in Myanmar: The Case of the Rohingya". Journal of International Studies (JIS), 7.

Sarkin, Jeremy. (2009). "The Role of The United Nations, the African Union and 
Africa's Sub Regional Organization in Dealing with Africa's Human Rights Problem: Connecting Humanitarian Intervention and Responsibility to Protect". Journal of African Law, 53, (1).

Struet, Michael J. (2006). "The Transformation of State Sovereign Rights and Responsibilities Under the Rome Statute for the International Criminal Court". Chapman Law Review, 8, (1).

Saragih, Santa Merelda. (2018) "Responsibility to Protect: Suatu Tanggung Jawab dalam Kedaulatan Negara". Jurnal Lantera Hukum, 5, (1).

Trisnanto, A. (2012). Eropa dalam Asia: Adopsi atau Imitasi? ASEAN dalam Konteks Integrasi dengan Model Eu. Interaktif, 1(1), 243605.
Yihdego, Zeray. (2011). "The African Union: Founding Principles, Frameworks and Prospects". European Law Joernal, 17, (5).

\section{Internet}

Laporan United Nations Human Rights Office of The High Commissioner. (2020).

Lihat, https://www.ohchr.org/EN/NewsEvents/ Pages/Myanmar ReportDetails.aspx (diakses pada 10 September 2020).

Human Rights Watch on Thailand Event. (2018) Lihat, https://www.hrw.org/worldreport/2019/country-chapters/thailand (diakses pada 10 September 2020).

Terms of References of ASEAN Intergovernmental Commission On Humam Rights Lihat, https://www.africancourt.org/en/ (diakses pada 7 Oktober 2020). 